\title{
THE SURVEY OF GROWTH AND DEVELOPMENT OF INFANTS AND CHILDREN IN A REMOTE, LOW-ECONOMIC DISTRICT IN THE MOUNTAINOUS CENTRAL KYUSHU, JAPAN
}

\author{
IICHIRO FUNATSU, SADAE TOMITA, \\ JUNICHI TOYODA, YOSHIO HATASE \\ AND SADAKO YAMAWAKI
}

Department of Pediatrics, Kurume University School of Medicine,

Kurume-city, Japan

In remote mountainous areas ${ }^{\left.1233^{345}\right)}$, infants and children generally show retarded growth and development as compared with those in urban and rural districts. The authors had several opportunities to care for and to treat these underdeveloped infants and children living in the mountainous area, Yabe-Kuroki in Fukuoka Prefecture, when they participated in the summer medical activities of their School of Medicine.

This paper is to provide data on the growth and development of infants and children and to contribute to the improvement of infant nursing and the promotion of lunch preparation in the schools in mountainous areas.

\section{MATERIAL AND METHOD}

\section{Surveyed area}

The investigated area occupied $250 \mathrm{~km}^{2}$ in extent and was on the auerage 500 meters above sea level. It was situated in the midst of one of the branches of the Central Kyushu Mountain Range and was $40 \mathrm{~km}$ south-east of Kurume City (Fig. 1 and 2). This area was divided into ten scattered primary school regions, which were 4 to $6 \mathrm{~km}$ away from the bus road, passing through the area along the river. The regions were located in the valleys or just below the summits of mountains. This area had a population of 28,509 in 1960, and the people lived by small-scaled farming, forestry and physical labor in each of the localities.

\section{Materials}

The material of the survey was 7,268 annual records of regular physical examinations of school children during the period from 1948 to 1959 . As the objectives of further studies, four out of ten school regions were selected according to consultation with a pediatrician and the local communities in this district. Involved were 233 school children and 611 preschool children, one to five years of age. The children received physical examinations, and sera from all of the 
school children and 158 of the younger children were obtained in 1959.

Fig. 1. Geographic Position of Surveyed Area.

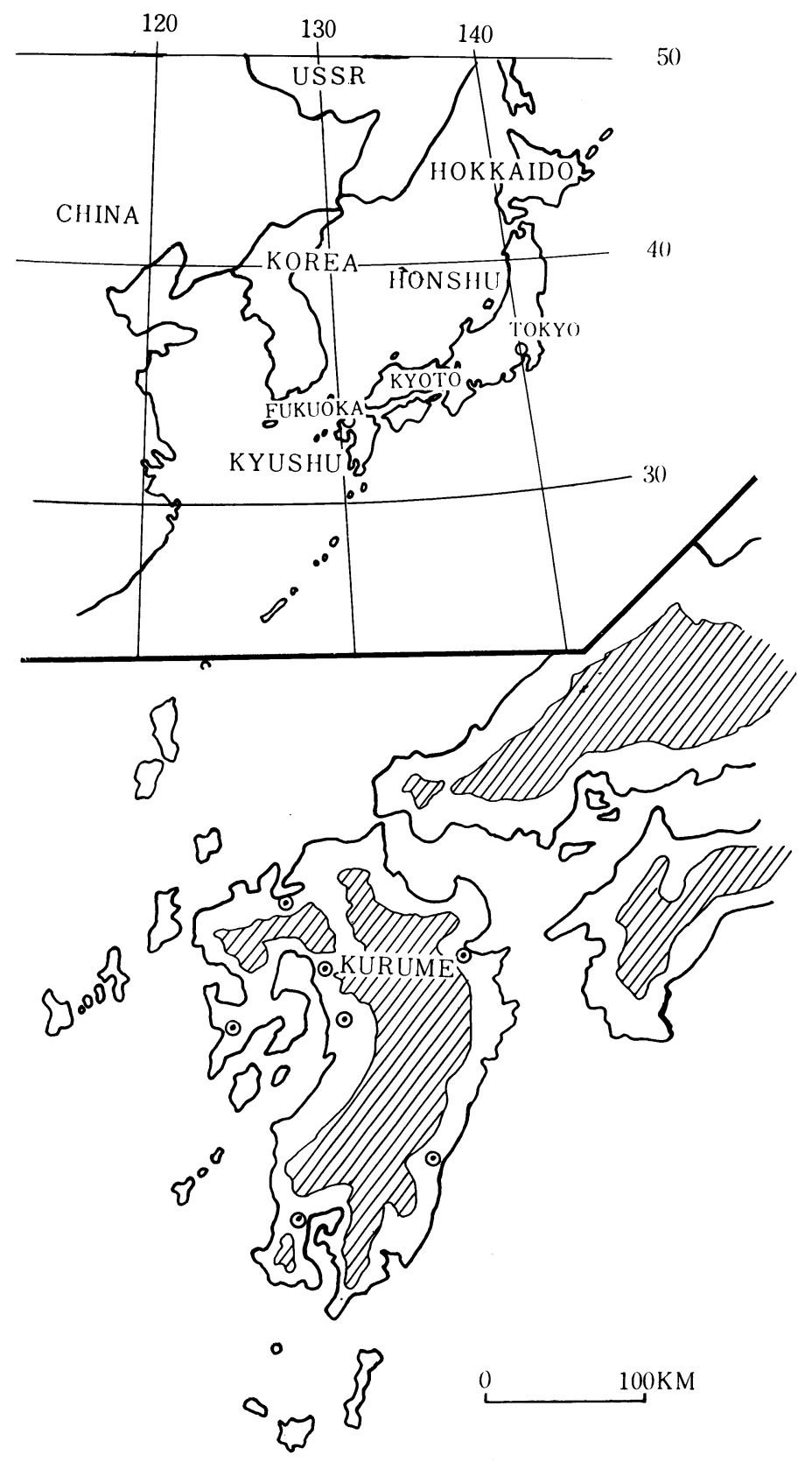


Fig. 2. Yabe-Kuroki Area in Fukuoka Prefecture.

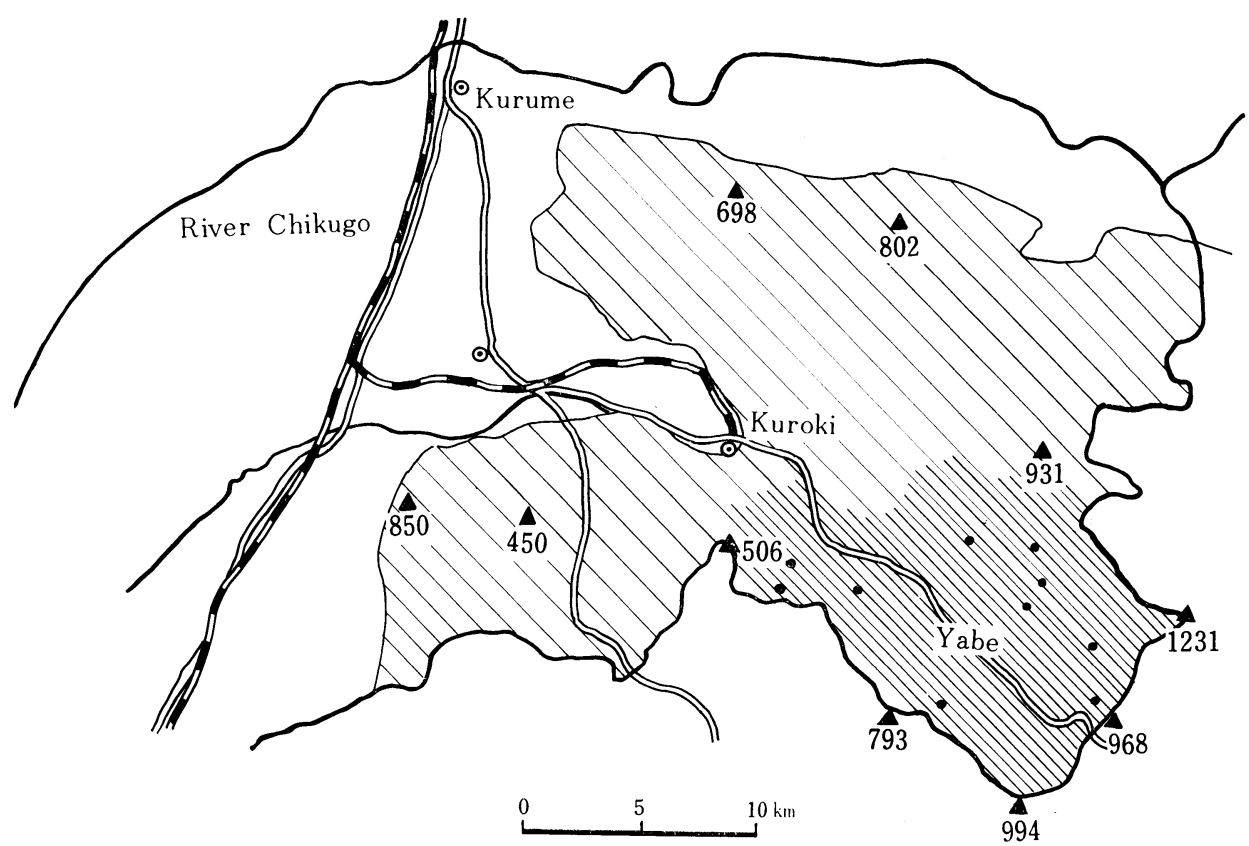

RESULTS

\section{Beginning and ending months of weaning}

Mothers usually began to wean their infants at six months of age, being one month later than the average in Japan (Tab. 1). But the ending month of weaning was prolonged to more than 18 months of age among half of the infants in this area, while the majority of infants were completely weaned by at least one year and a half in Japan (Tab. 2). Through a physical examination of weaning infants it was revealed that $24 \%$ were insufficient in weight and were under-

TABLE 1

Beginning Months of the Weaning

\begin{tabular}{|c|c|c|c|c|c|c|c|c|c|c|}
\hline Area & & $<5$ & 5 & 6 & 7 & 8 & 9 & 10 & 11 & $12<$ \\
\hline \multirow{2}{*}{ Yabe, Kuroki } & No. & 1 & 2 & 32 & 21 & 35 & 6 & 10 & 5 & 19 \\
\hline & $\%$ & 0.7 & 1.5 & 24.4 & 16.0 & 26.7 & 4. 6 & 7.6 & 3.8 & 14.5 \\
\hline \multirow{2}{*}{ Japan } & No. & 199 & 379 & 287 & 549 & 329 & 102 & 110 & 37 & 91 \\
\hline & $\%$ & 7.5 & 14.2 & 29.8 & 20.6 & 12.3 & 3.8 & 3.9 & 1.4 & 3.4 \\
\hline \multirow{2}{*}{ Fukuoka pref } & No. & 19 & 52 & 105 & 118 & 73 & 24 & 33 & 11 & 44 \\
\hline & $\%$ & 4. 0 & 10.8 & 22.0 & 24.6 & 15.2 & 5.0 & 6.9 & 2.3 & 9.2 \\
\hline
\end{tabular}


nourished, although undernourishment is found in less than $10 \%$ of rural districts in Fukuoka Prefecture (Tab. 3).

TABLE 2

Ending Months of the Weaning

\begin{tabular}{lr|r|r|r|r|r|r|r|r|r|r|r|r|r}
\hline Area & 6 & 7 & 8 & 9 & 10 & 11 & 12 & 13 & 14 & 15 & 16 & 17 & $18<$ \\
\hline $\begin{array}{l}\text { Yabe, } \\
\text { Kuroki }\end{array}$ & No. & 0 & 0 & 0 & 0 & 1 & 4 & 17 & 4 & 4 & 11 & 1 & 4 & 33 \\
\hline & & & & & 1.2 & 5.0 & 21.5 & 5.5 & 5.5 & 13.5 & 1.2 & 5.0 & 41.8 \\
\hline Japan & No. & 8 & 4 & 27 & 20 & 53 & 53 & 178 & 56 & 75 & 53 & 35 & 26 & 88 \\
\hline $\begin{array}{l}\text { Fukuoka } \\
\text { pref. }\end{array}$ & 1.1 & 0.5 & 3.8 & 2.8 & 7.5 & 7.5 & 25.2 & 7.9 & 10.6 & 7.5 & 4.9 & 3.6 & 12.4 \\
\hline
\end{tabular}

TABLE 3

Growth and Development of Weaning Infants in the Investigated Area

\begin{tabular}{l|r|r|r|r|r}
\hline Nutrition & better & good & moderate & undernourished & total \\
\hline $\begin{array}{l}\text { No. of infants } \\
\%\end{array}$ & 21 & 12 & 96 & 41 & 170 \\
\hline
\end{tabular}

\section{Length and weight of preschool children}

The average length attained $98.6 \%$ and $99.5 \%$ and tha average weight $96.6 \%$ and $96.1 \%$ of the national averages in boys and girls, respectively (Fig. 3, 4). The growth in length and weight became slower at four years of age in both boys and girls.

\section{Length, Weight and Rohrer index of school children}

During these eleven years from 1948 to 1959, no differences were found in the annual increasing rates of length and weight between the area averages and the national averages for both sexes. That is, the rates of length were $4.4 \%(4.4$ $\%$ ) and $4.3 \%(4.6 \%)$ and those of weight $10 \%(12 \%)$ and $11 \%(11 \%)$ in boys and girls, respectively, the numbers in parentheses showing the national averages (Fig. 5, 6, 7, 8). Although there has been a slow increase in stature from 1.8 $\%$ to $0.2 \%$ in boys and from $4.8 \%$ to $1.2 \%$ in girls, and that in weight form $9.8 \%$ to $1.7 \%$ in boys and from $7.8 \%$ to $7.7 \%$ in girls in these eleven years, the growth in length and weight were retarded by $2 \%$ and $3.5 \%$ in both sexes in comparison with the national averages.

Their Rohrer indices showed higher values in the upper school grades, and they began to show the typical stature of mountainous districts (Fig. 9). 
Fig. 3. Average Growth Curves in Length 1959.

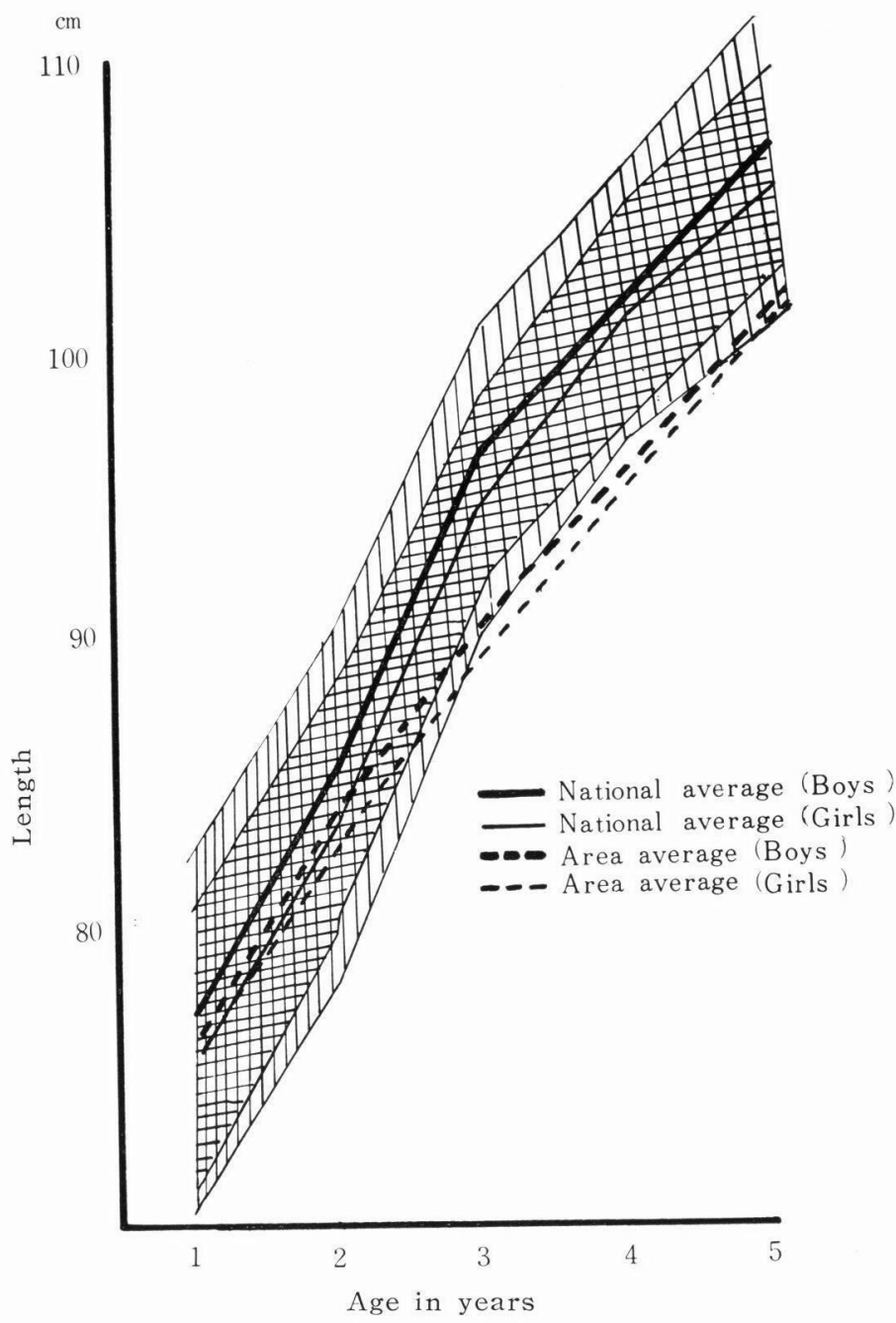

\section{Lunch}

The dryness of skin, anemia, angular stomatitis and accentuation of the pulmonary second heart sound were frepuently observed among these children. Since uudernourishment seemed to prevaile among school children at the beginning of the survey, an attempt was made to study their diet. To be certain of the daily diet of pupils, the authors examined without previous announcement the home-prepared lunch which the pupils used to bring to school everyday as was the usual manner of school children formerly in the rural districts. The lunches of 232 children were weighed and examined as follows:

1) Qualitative analysis of lunch food

Basic foodstuffs were rice and wheat, and they were usually mixed in a pro- 
Fig. 4. Aberage Growth Curves in Weicht, 1959.

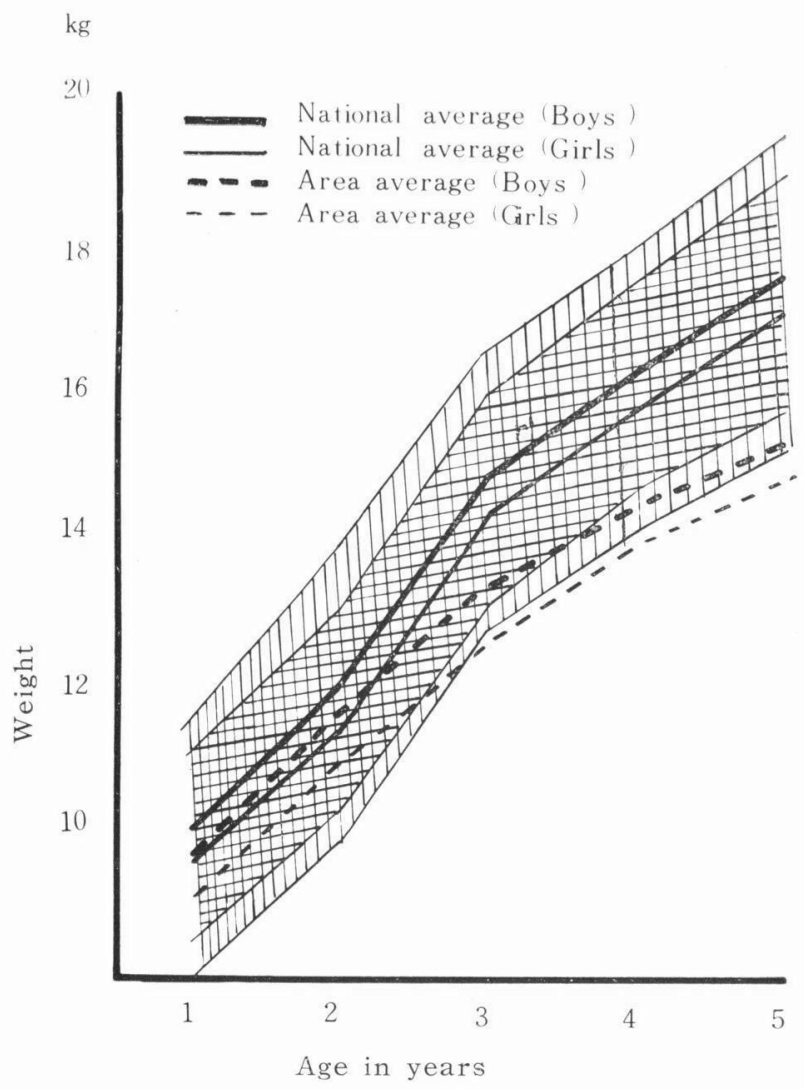

portion of 65 parts of rice to 35 parts of wheat. Usually in each of the lunches vegetable and animal foods were added in small amounts. $82 \%$ of these added foods were simple preserved preparations. The preserved vegetables were mainly pickled radish, fried pickled vegetables and salted tangle, and the preserved animal foods were mainly fish powder, roasted or fried fith paste, soy cooked sea slug, slices of bonito, sausage and salted whale (Tab. 4).

\section{2) Quantitative analysis of lunch food}

In Tab. 5, total calories, protein, fat and carbohydrate intake are presented separately according to the grades of school. The amount of total calories ranged from 508 to $570 \mathrm{Cal}$, with an average of $518 \mathrm{Cal}$, and this covered $86 \%$ of the caloric requirement for a standard school lunch. Ninety-four per cent of the total calories was derived from the basic foodstuff. The protein intake was $12 \mathrm{~g}$ on the average and it was half the allowance of the standard lunch regimen for Japanese school children. The protein of animal origin was predominantly supplied by preserved fish preparations and it amounted to only $2 \mathrm{~g}$. The remaining proportion of protein was obtained from rice and wheat. The fat intake was $2.6 \mathrm{~g}$ on the average and it was a quarter of the standard allowance of the lunch 
Fig. 5. Average Increment by Year in Length During 1948 to 1959 (Boys).

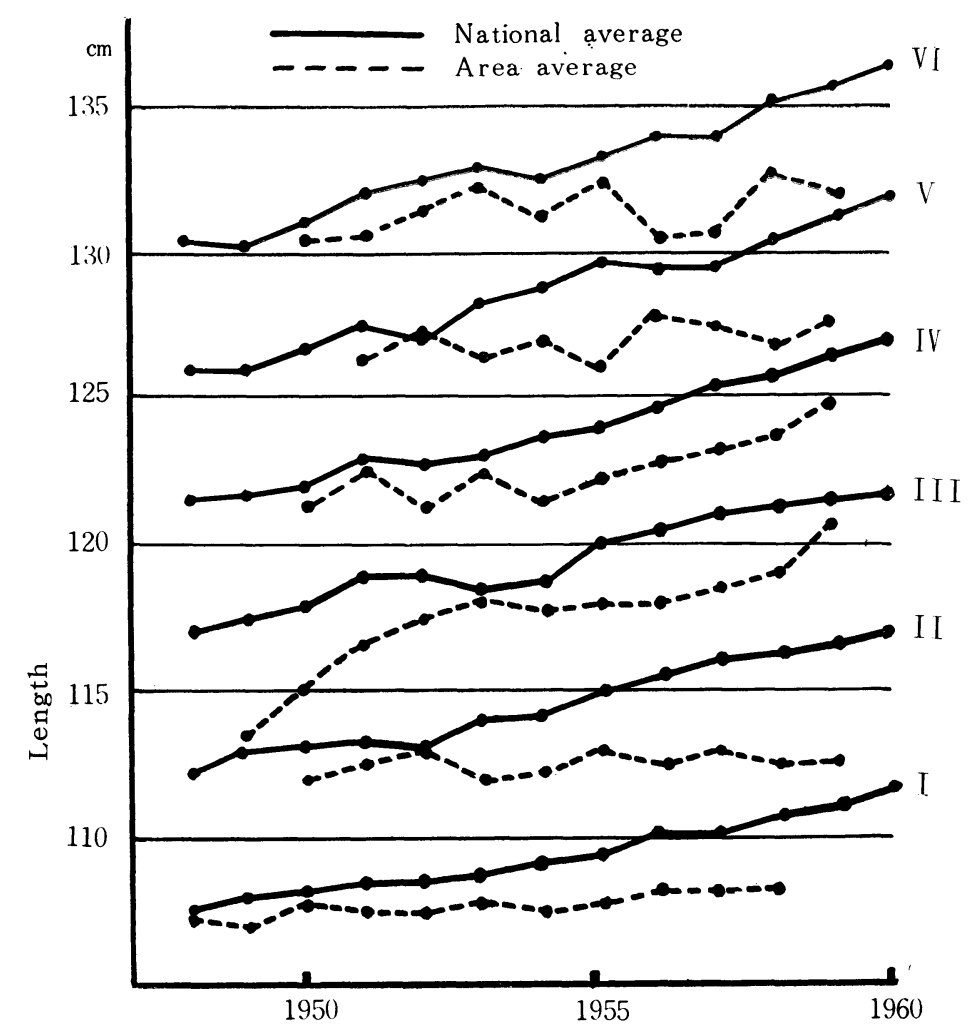

TABLE 4

Constitvents of Lunch Food of School Children

\begin{tabular}{|c|c|c|c|c|c|c|}
\hline \multicolumn{2}{|c|}{ Food Primary schools } & $\mathrm{H}$ & $\mathrm{O}$ & $\mathrm{O}$ & Total & $\%$ \\
\hline \multicolumn{2}{|l|}{ Rice } & 18 & 5 & 1 & 24 & 10.5 \\
\hline \multicolumn{2}{|l|}{ Wheat \& Rice } & 73 & 72 & 63 & 208 & 89.5 \\
\hline \multirow{2}{*}{$\begin{array}{l}\text { Vegetable } \\
\text { foods }\end{array}$} & $\begin{array}{l}\text { Preserved } \\
\text { foods }\end{array}$ & 52 & 60 & 31 & 143 & 81.8 \\
\hline & Cooked foods & 12 & 13 & 8 & 33 & 18.2 \\
\hline \multirow{2}{*}{ Animal foods } & $\begin{array}{l}\text { Praserved } \\
\text { foods }\end{array}$ & 60 & 30 & 10 & 100 & 82.0 \\
\hline & Cooked foods & 7 & 13 & 2 & 22 & 18.0 \\
\hline
\end{tabular}


Fig. 6. Average Increment by Year in Length During 1948 to 1959 (Girls).

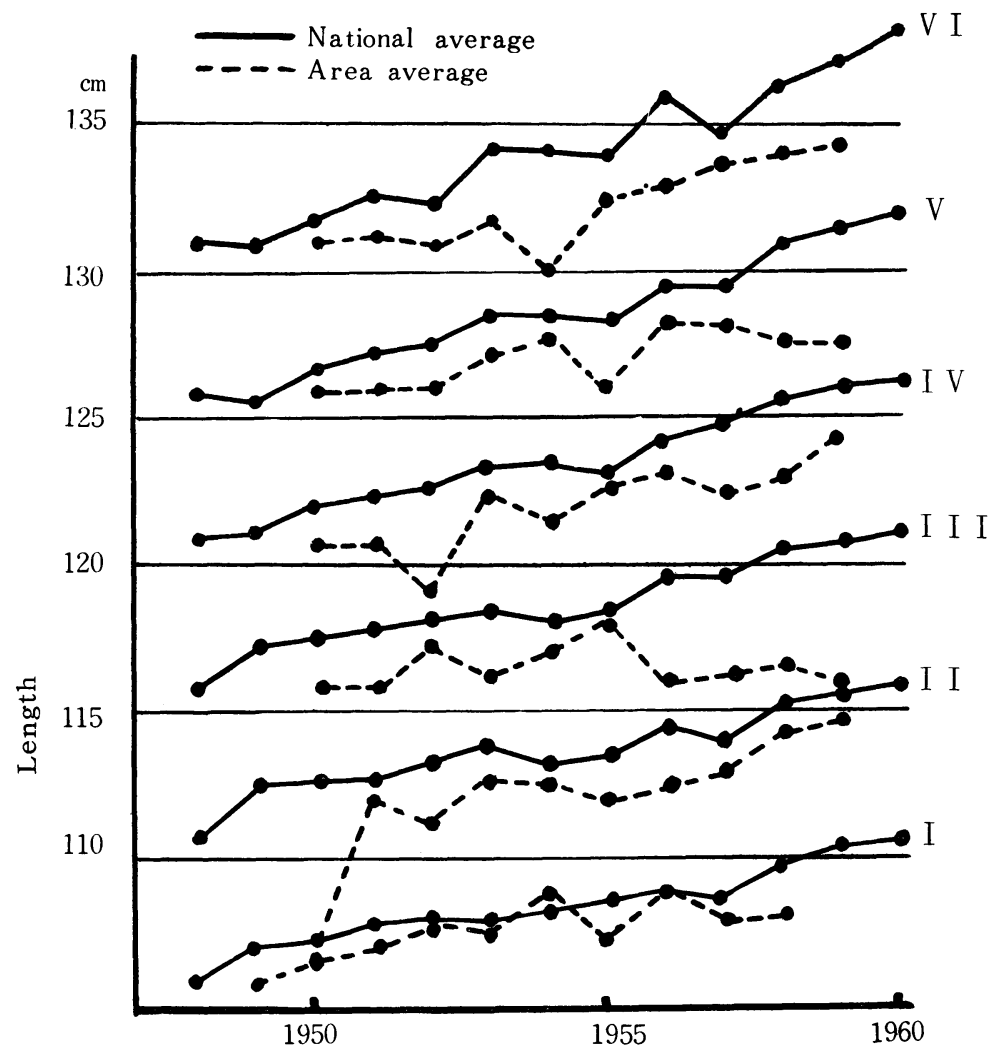

TABLE 5

Total Calories and Constituents of Lunches of Pupils

\begin{tabular}{c|c|c|c|c|c|c|c|c}
\hline $\begin{array}{c}\text { Grade of } \\
\text { School }\end{array}$ & $\begin{array}{c}\text { Total } \\
\text { Cal }\end{array}$ & $\begin{array}{c}\text { Animal } \\
\text { Protein g }\end{array}$ & $\begin{array}{c}\text { Vegetable } \\
\text { Protein g }\end{array}$ & $\begin{array}{c}\text { Total } \\
\text { Protein }\end{array}$ & Prot/kg & Fat & $\begin{array}{c}\text { Carbohy- } \\
\text { drate }\end{array}$ & $\begin{array}{c}\text { Carboh/ } \\
\text { Tot. Cal. }\end{array}$ \\
\hline 1 & 493 & 2.63 & 9.25 & 11.88 & 0.646 & 3.0 & 107 & 85 \\
2 & 520 & 1.87 & 10.15 & 12.02 & 0.584 & 2.3 & 114 & 87 \\
3 & 533 & 1.74 & 9.76 & 11.50 & 0.519 & 2.8 & 119 & 87 \\
4 & 566 & 1.68 & 10.28 & 11.96 & 0.495 & 2.3 & 108 & 88 \\
5 & 566 & 1.42 & 10.36 & 11.78 & 0.457 & 2.4 & 115 & 88 \\
6 & 566 & 1.54 & 9.96 & 11.50 & 0.391 & 2.4 & 121 & 88 \\
\hline Total & 541 & 1.81 & 9.97 & 11.78 & 0.517 & 2.5 & 114 & 87 \\
\hline
\end{tabular}

regimen.

This investigation revealed that the protein and fat intake in everyday lunches were deficient in quantity and unbalanced in quality. 
Fig. \%. Average Increment by Year in Weight During 1948 to 1959 (Boys)

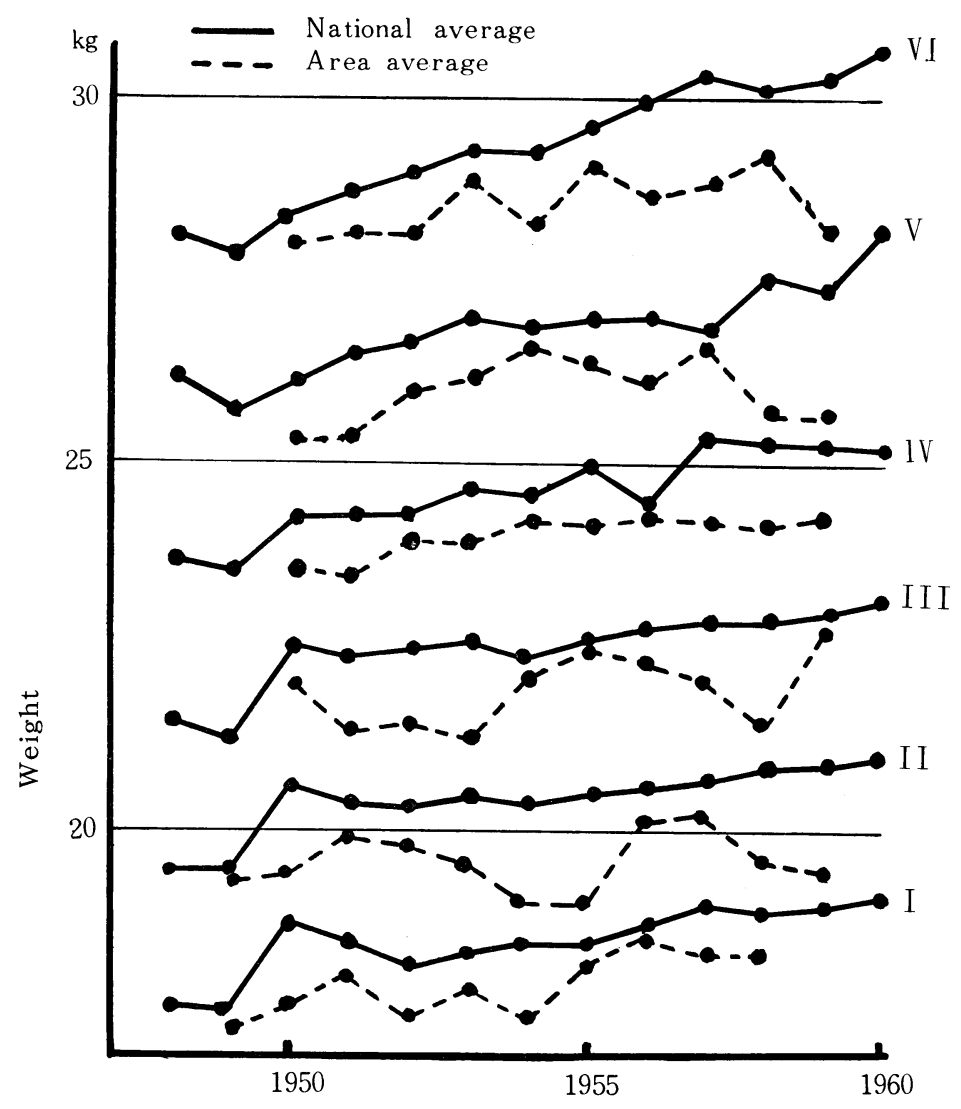

\section{Protein and fat content of sera of children}

As was previously described, the factor responsible for latent malnutrition invariably persisted among these children. Three hundred ninety serum samples were collected from preschool and school children just before lunch time. The total protein in the serum was $6.6 \mathrm{~g}$ per $100 \mathrm{ml}$ in younger children and $7.3 \mathrm{~g}$ per $100 \mathrm{ml}$ in school children, showing the lower values of the normal range of serum protein. Protein fractions of serum were determined through paper electrophoresis. Albumin, $\alpha_{1-}, \alpha_{2}-, \beta$ - and $\gamma$-globulin contents of serum were, respectively, $3.83 \mathrm{~g}, 0.22 \mathrm{~g}, 0.65 \mathrm{~g}, 0.78 \mathrm{~g}$ and 1.23 per $100 \mathrm{ml}$ in preschool children, and 3.99 $\mathrm{g}, 0.32 \mathrm{~g}, 0.65 \mathrm{~g}, 0.77 \mathrm{~g}$ and $1.51 \mathrm{~g}$ in school children (Tab. 6). There was an indication from the electrophoretical analysis that hypoalbuminemia and hypergammaglobulinemia existed in mild degree and the ratio of albumin to globulin decreased slightly.

Total fat varied from $590 \mathrm{mg}$ to $612 \mathrm{mg}$, with an average of $613 \mathrm{mg}$ per $100 \mathrm{ml}$ in preschool children and from $635 \mathrm{mg}$ to $713 \mathrm{mg}$, with an average of $667 \mathrm{mg}$ per $100 \mathrm{ml}$, in school children. These averages attained $80 \%$ of the normal values of the fat content of serum. The content of $\alpha$-lipoprotein in percentile was 
Fig. 8. Average Increment by Year in Weight During 1948 to 1959 (Girls)

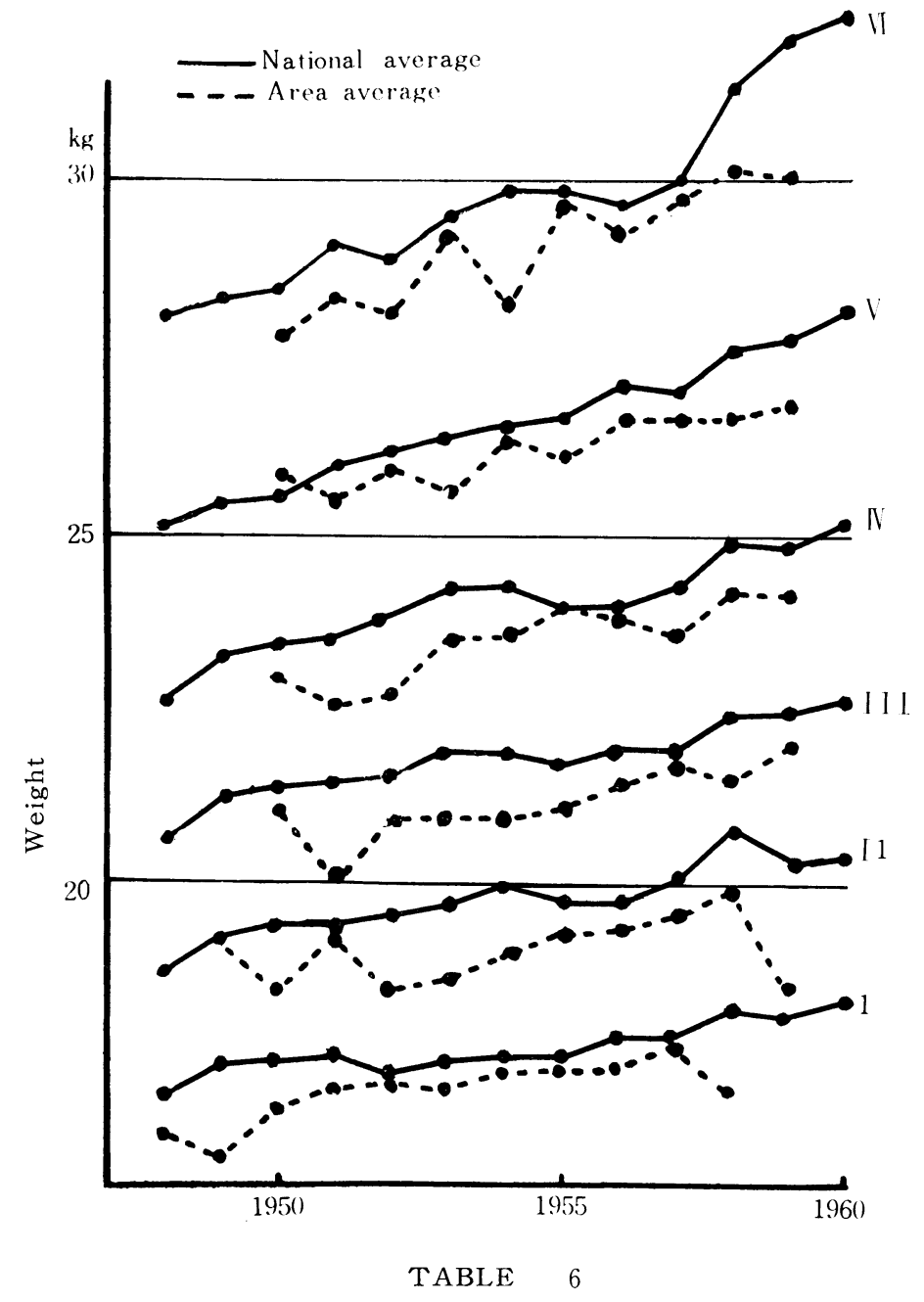

Total Protein and Protein Fractions $A / G$ Ratio of Serum

\begin{tabular}{c|c|c|c|c|c|c|c|c}
\hline $\begin{array}{c}\text { Age in } \\
\text { year }\end{array}$ & $\mathrm{n}$ & $\begin{array}{c}\text { Total } \\
\text { Protein }\end{array}$ & Albumine & $\alpha_{1}-\mathrm{G} 1$ & $\alpha_{2}-\mathrm{G} 1$ & $\beta-\mathrm{G} 1$ & $\gamma-\mathrm{Gl}$ & $\mathrm{A} / \mathrm{G}$ \\
\hline $1-2$ & 17 & 6.82 & 3.93 & 0.26 & 0.73 & 0.78 & 1.05 & 1.44 \\
$2-3$ & 33 & 6.79 & 3.17 & 0.25 & 0.75 & 0.82 & 1.19 & 1.28 \\
$3-4$ & 45 & 6.74 & 3.69 & 0.26 & 0.74 & 0.85 & 1.31 & 1.26 \\
$4-5$ & 33 & 6.43 & 3.60 & 0.20 & 0.67 & 0.67 & 1.30 & 1.26 \\
$5-6$ & 25 & 6.74 & 4.01 & 0.18 & 0.61 & 0.61 & 1.28 & 1.49 \\
$6-7$ & 31 & 7.29 & 4.14 & 0.27 & 0.68 & 0.84 & 1.39 & 1.34 \\
$7-8$ & 41 & 7.31 & 3.90 & 0.32 & 0.69 & 0.84 & 1.57 & 1.19 \\
$8-9$ & 44 & 7.35 & 4.11 & 0.31 & 0.63 & 0.83 & 1.53 & 1.53 \\
$9-10$ & 40 & 7.04 & 3.61 & 0.35 & 0.63 & 0.89 & 1.57 & 1.06 \\
$10-11$ & 31 & 7.20 & 3.99 & 0.28 & 0.62 & 0.85 & 1.53 & 1.32 \\
$11-12$ & 45 & 7.52 & 4.15 & 0.25 & 0.64 & 0.87 & 1.60 & 1.30 \\
\hline
\end{tabular}


Fig. 9. Graphs of Rohrer Indeces of School Boys and Girls.

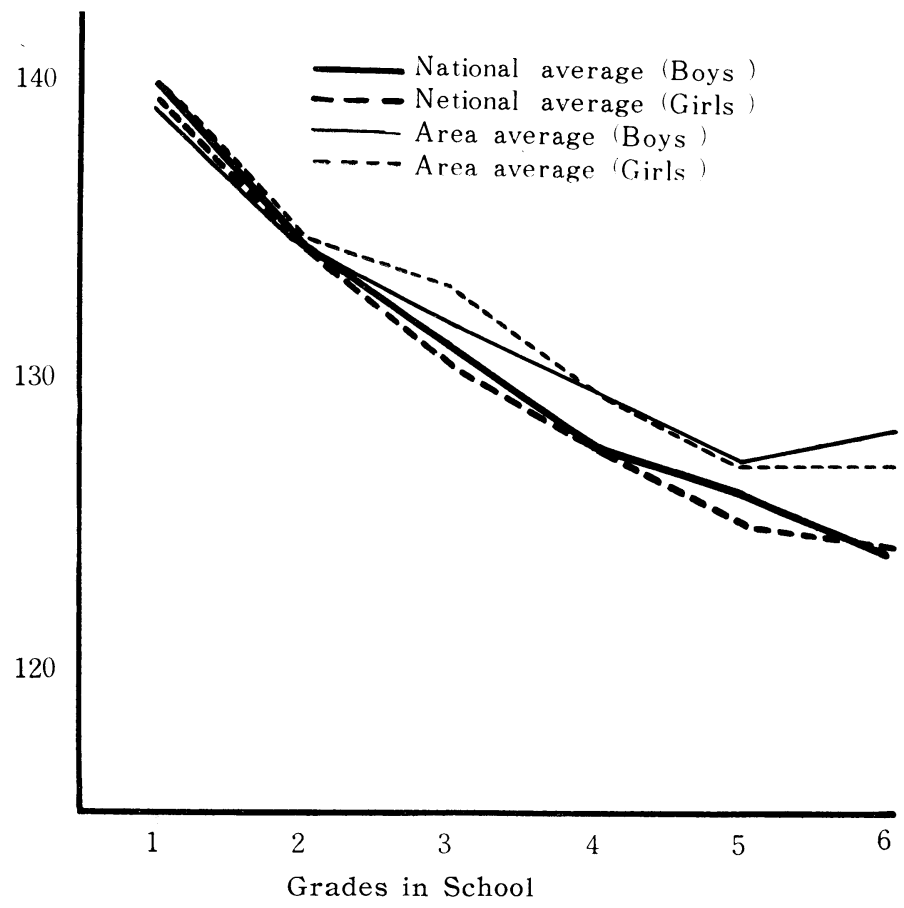

approximately normal at $36.6 \%$ and $34.4 \%$. That of $\beta$-lipoprotein in percentile was slightly decreased to $44.8 \%$ and $38.9 \%$ in preschool and school children, respectively. The ratio of $\beta$-lipoprotein to $\alpha$-lipoprotein was lowered to 1.44 and 1.32 respectively, in both groups of children in contrast with the normal values 1.90 (Tab. 7).

TABLE 7

Total FAT and Lipoprotein in Percent in Serum

\begin{tabular}{r|l|l|l|l|l|l|l}
\hline $\begin{array}{c}\text { Age in } \\
\text { year }\end{array}$ & $\mathrm{n}$ & $\begin{array}{c}\text { Total } \\
\text { fat }\end{array}$ & $\mathrm{n}$ & $\alpha$-LP & $\beta-\mathrm{LP}$ & $\gamma-\mathrm{LP}$ & $\beta / \alpha$ \\
\hline $1-2$ & 14 & 637 & 12 & 38.9 & 48.7 & 12.9 & 1.46 \\
$2-3$ & 30 & 590 & 26 & 33.0 & 44.2 & 18.7 & 1.38 \\
$3-4$ & 37 & 601 & 26 & 37.0 & 48.7 & 15.2 & 1.59 \\
$4-5$ & 29 & 612 & 29 & 36.2 & 39.8 & 23.8 & 1.17 \\
$5-6$ & 19 & 611 & 21 & 34.6 & 37.0 & 27.7 & 1.19 \\
$6-7$ & 27 & 641 & 17 & 30.3 & 43.7 & 25.8 & 1.35 \\
$7-8$ & 37 & 662 & 27 & 33.2 & 43.9 & 22.8 & 1.39 \\
$8-9$ & 38 & 635 & 40 & 39.7 & 37.1 & 24.2 & 1.08 \\
$9-10$ & 39 & 660 & 32 & 36.0 & 43.8 & 20.1 & 1.42 \\
$10-11$ & 26 & 713 & 24 & 32.9 & 43.1 & 23.8 & 1.40 \\
$11-12$ & 24 & 674 & 38 & 35.5 & 41.3 & 25.8 & 1.31 \\
\hline
\end{tabular}




\section{COMMENTS}

Since a gradual gain in height and weihgt was continuously observed for eleven years and the annual increasing rate showed the same pattern as the national average, the acceleration phenomenon of growth took place even in the remote mountainous area. Not only the records of regular physical examinations, but also recent investigation, however, revealed retardation of growth compared to the national averag. Among the factors influencing growth, malnutrition should naturally be taken into consideration.

The prolongation of the weaning period and an inadequate diet invariably affected the growth and development of infants. The home-prepared lunches of the pupils were deficient in protein and fat, and the home diet would not, therefore, differ much from the lunch food. Since their nutritional requirements mainly depend upon rice and wheat, there consequently would result an insufficiency of protein and fat intake in both proportion and amount, even if daily soya would partially compensate for this deficit. In reality, hypoalbuminemia and hypolipemia are frequently detected throughout childhood and they reveal the exsistence of latent malnutrition, sometimes showing the clinical signs of it.

From this survey, it is evident that children are often suffering from latent malnutrition and their growth is in greater or lesser extent affected in the remote mountainous area ${ }^{6}$.

The communities have discussed these actual aspects of child growth and nutritional state, and school lunch preparation has been realized in all of the primary schools within one year and a half. Instruction in infant nursing took place very often in each locality.

\section{SUMMARY}

We have investigated the infants and children in the remote, low-economic area in the mountainous Central Kyushu through recent records of annual physical examinations and the actual examination of their lunch foods and blood sera. Although the acceleration phenomenon observed among these children, they showed the retarded growth in comparison with the national averages. Prolonged weaning affected considerably the growth and development of infants. The examination of the lunches of school children revealed the deficiency in the nutritional supply particularly in protein and fat because their daily diet depends mainly upon the basic rice and wheat. Subsequent hypoalbuminemia and hypolipemia revealed that latent malnutrition prevailed among the infants and children studied. In order to improve child growth, the communities have realized school lunch preparation and have promoted instruction in infant nursing within one year and a half fron this survey.

\section{REFERENCES}

1) Abe, K., Ichinose, H. and Yano, K. : Difference of Body Development of School Boy Seen in the Communities. J. Kurume M. A., 19, 548, 1956. 
2. NaKano,H. : The Speciality and Influence of the Environment upon Somatic Development of School Children in the Village between Mountains. J. Kurume M. A., 19, 1985, 1956.

3. Morotomi, T., Yoshitsugu, K. and Morotomi, Y. : Characteristics of Body Construction and Strength of School Children in a Mountainous Region. J. Kurume M. A., 2., 1461, 1960.

4. Furukawa, T. : Studies on the Process of Growth of School Chileren in Sasebo-City Nagasaki-Prefecture. J. Kurume M. A., 28, 381, 1960.

5. Mrzose, M. : On the Intelligence Quotient and the Growth of School Children in Farming and Fishing Village. J. Kurume M. A., 2:, 2240, 1960.

6. Tomita, S. : Survey of the Nutritional Status of Young and School Children of Remote, Low Economic District in Mountainous Middle Kyushu, J. Kurume M. A., 24, 1375, 1961. 